\title{
CONTENTS OF VOLUME 47
}

D. ABBOTT: See E. S. KEY

RAVI P. AGARWAL, DONAL O'REGAN and PATRICIA J. Y. WONG: On constant-sign periodic solutions in modelling the spread of interdependent epidemics

C. N. ANESTOPOULOS and E. E. ARGYROPOULOS: On the low frequency asymptotics for the 2-D electromagnetic transmission problem

TADEUSZ ANTCZAK: Saddle point criteria and duality in multiobjective programming via an $\eta$-approximation method

E. E. ARGYROPOULOS: See C. N. ANESTOPOULOS

P. C. BAGGA: See LAXMI NARAIN

F. BAHRAMI: See B. EMAMIZADEH

R. J. BAXTER: Hyperelliptic parametrisation of the generalised order parameter of the $N=3$ chiral Potts model

KENNETH S. BERENHAUT, EVA G. GOEDHART and STEVO STEVIĆ: Explicit bounds for third-order difference equations

P. K. BHATTACHARYA: See J. MAZUMDAR

X. D. CHEN: See M. I. NELSON

ZU-CHI CHEN: See K. FAKHAR

B. D. CRAVEN: Optimal control on an infinite domain

IDRIS DAĞ: See DURSUN IRK

F. DAL and G. SH. GUSEINOV: A boundary value problem for second-order nonlinear difference equations on the integers

ABDÜLKADIR DOĞAN: See DURSUN IRK

GUANG-REN DUAN: See YAN-MING FU

G. F. D. DUFF, R. B. LEIPNIK and C. E. M. PEARCE: Guide expansions for the recursive parametric solution of polynomial dynamical systems

B. EMAMIZADEH and F. BAHRAMI: Existence of seamount steady vortex flows

K. FAKHAR, ZU-CHI CHEN and XIAODA JI: Symmetry analysis of rotating fluid

L. K. FORBES: See T. E. STOKES

LARRY K. FORBES: See ANGUS I. S. MUNRO

LARRY K. FORBES: See CLAIRE E. TRENHAM

I. FRANJIĆ: See J. PEČARIĆ

YAN-MING FU, DI WU and GUANG-REN DUAN: Robust guaranteed cost control for descriptor systems with Markov jumping parameters and state delays

A. GHOSH: See J. MAZUMDAR

EVA G. GOEDHART: See KENNETH S. BERENHAUT

FAMING GUO, BIN TANG and FALUN HUANG: Robustness with respect to small delays for exponential stability of abstract differential equations in Banach spaces

ZHIMING GUO: See ZHAN ZHOU

G. SH. GUSEINOV: See F. DAL 
P. M. HAESE: Cavities at atmospheric pressure behind two-dimensional bodies at an angle of attack

J. S. HEWITT: See J. MAZUMDAR

G. C. HOCKING: See T. E. STOKES

FALUN HUANG: See FAMING GUO

N. Q. HUY, V. JEYAKUMAR and G. M. LEE: Sufficient global optimality conditions for multiextremal smooth minimisation problems with bounds and linear matrix inequality constraints

DURSUN IRK, IDRIS DAĞ and ABDÜLKADIR DOĞAN: Numerical integration of the RLW equation using cubic splines

L. S. JENNINGS: See S. MUNZIR

V. JEYAKUMAR: See N. Q. HUY

XIAODA JI: See K. FAKHAR

E. S. KEY, M. M. KŁOSEK and D. ABBOTT: On Parrondo's paradox: how to construct unfair games by composing fair games

M. M. KŁOSEK: See E. S. KEY

M. T. KOH: See S. MUNZIR

J. A. LEACH: A note on the small-time development of the solution to a coupled, nonlinear, singular reaction-diffusion system

G. M. LEE: See N. Q. HUY

R. B. LEIPNIK: See G. F. D. DUFF

ROY B. LEIPNIK and C. E.M. PEARCE: Diversity sensitivity and multimodal Bayesian statistical analysis by relative entropy

BIWEN LI: See ZHENGQIU ZHANG

XINZHI LIU, XUEMIN SHEN and YI ZHANG: A comparison principle and stability for largescale impulsive delay differential systems

J. MAZUMDAR, A. GHOSH, J. S. HEWITT and P. K. BHATTACHARYA: Elastic plastic analysis of shallow shells-a new approach

G. D. MCBAIN: Plane poloidal-toroidal decomposition of doubly periodic vector fields. Part 1. Fields with divergence

G. D. MCBAIN: Plane poloidal-toroidal decomposition of doubly periodic vector fields. Part 2. The Stokes equations

ANGUS 1. S. MUNRO and LARRY K. FORBES: Including ionisation in a simple model of single-bubble sonoluminescence

S. MUNZIR, L. S. JENNINGS and M. T. KOH: Computational models satisfying relative angle constraints for 2-dimensional segmented bodies

LAXMI NARAIN and P. C. BAGGA: Flowshop/no-idle scheduling to minimise the mean flowtime

M. I. NELSON, X. D. CHEN and M. J. SEXTON: Analysis of the Michaelis-Menten mechanism in an immobilised enzyme reactor

DONAL O'REGAN: See RAVI P. AGARWAL

JONG YEOUL PARK and SUN HYE PARK: Existence of solutions and optimal control problems for hyperbolic hemivariational inequalities

SUN HYE PARK: See JONG YEOUL PARK

C. E. M. PEARCE: See G. F. D. DUFF

C. E. M. PEARCE: See ROY B. LEIPNIK

J. PEČARIĆ and I. FRANJIĆ: Generalisation of corrected Simpson's formula 
JEAN-PAUL PENOT and CONSTANTIN ZĂLINESCU: Some problems about the representation of monotone operators by convex functions

P. RAJA SEKHARA RAO: See V. SREE HARI RAO

V. SREE HARI RAO and P. RAJA SEKHARA RAO: Stability analysis of resource-consumer dynamic models

M. J. SEXTON: See M. I. NELSON

XUEMIN SHEN: See XINZHI LIU

STEVO STEVIĆ: See KENNETH S. BERENHAUT

T. E. STOKES, G. C. HOCKING and L. K. FORBES: Unsteady flow induced by a withdrawal point beneath a free surface

BIN TANG: See FAMING GUO

CLAIRE E. TRENHAM and LARRY K. FORBES: A comparison of two- and three-variable models for combustion in sealed containers

PATRICIA J. Y. WONG: See RAVI P. AGARWAL

DI WU: See YAN-MING FU

YANG SHOUZHI: An algorithm for constructing biorthogonal multiwavelets with higher approximation orders

JIANSHE YU: See ZHAN ZHOU

BEONG IN YUN: Sigmoidal cosine series on the interval

CONSTANTIN ZĂLINESCU: See JEAN-PAUL PENOT

YI ZHANG: See XINZHI LIU

ZHENGQIU ZHANG, YUSEN ZHU and BIWEN LI: Periodic solutions of a nonlinear oscillatory system with two degrees of freedom

ZHAN ZHOU, JIANSHE YU and ZHIMING GUO: The existence of periodic and subharmonic solutions to subquadratic discrete Hamiltonian systems

SONG-PING ZHU: A closed-form analytical solution for the valuation of convertible bonds with constant dividend yield

YUSEN ZHU: See ZHENGQIU ZHANG 